\title{
RAB23 Gene
}

National Cancer Institute

\section{Source}

National Cancer Institute. RAB23 Gene. NCI Thesaurus. Code C106457.

This gene is involved in intracellular membrane trafficking. 